\title{
Celebrity Brand Ambassador and e-WOM as Determinants of Purchase Intention: A Survey of Indonesian Celebrity Cake
}

\author{
Safira Putri Utami ${ }^{1, *}$, Nuning Setyowati ${ }^{2}$, and Putriesti Mandasari ${ }^{3}$ \\ ${ }^{1}$ Student of Agribusiness Department, Faculty of Agriculture, Universitas Sebelas Maret, 57126 Jebres, Surakarta, Indonesia \\ ${ }^{2}$ Main Supervisor, Agribusiness Department, Faculty of Agriculture, Universitas Sebelas Maret, 57126 Jebres, Surakarta, Indonesia \\ ${ }^{3}$ Co-Supervisor, Agribusiness Department, Faculty of Agriculture, Universitas Sebelas Maret, 57126 Jebres, Surakarta, Indonesia
}

\begin{abstract}
This research aims to analyze the influence of celebrity brand ambassador, e-WOM quality, eWOM quantity, and sender's expertise on consumers' purchase intention of celebrity cake in Indonesia (Yogyakarta, Solo, and Semarang). The research areas are purposively chosen while a hundred of respondents are determined conveniently. Using the regression analysis as an analytical tool, the study shows that the model is significant, while the Celebrity brand ambassador and e-WOM quality have a positive influence on consumers' purchase intention of Indonesian celebrity cake. Celebrities as the brand ambassadors are known for their familiarity, good personalities, good interaction with the consumers (during promotion), and success in delivering the specific facts about celebrity cake. Meanwhile, viewing online reviews (clarity, understandability, credibility, reasonability) is helpful for consumers in building their confidence in purchase intention. The most influential variable on consumers' purchase intention of celebrity cake is a celebrity brand ambassador, based on the value of $\mathrm{B}$ in the Unstandardized Coefficients' table is 0.360 greater than other variables.
\end{abstract}

\section{INTRODUCTION}

Growing trends of online transaction and commercial Web sites among consumers induce a rapid growth of internet-based electronic commerce [46]. For the food and beverage businesses, the impact of celebrity as a brand ambassador and online reviewer is considered to be very important as consumers get a chance to know the product better before they purchase it. Through the digital commercial where consumers could freely deliver their ideas and comments, the term e-WOM also escalates as a powerful marketing tool which provides them exceeding information about the product [19]. Besides, there is a new strong marketing strategy that makes the advertisement of the product becomes more appealing and effective which to hire a celebrity, who is able to easily gain consumers' attention, to be a brand ambassador [7]. By combining the great power of eWOM and brand ambassador, running a business in highly competitive market as today seems to be possible, it can be seen in some successful celebrity cake businesses.

Use celebrity brand ambassador and e-WOM may be a powerful marketing tool. Using celebrity as a brand ambassador is effective because their popularity will help the advertisement of their product become more attractive and it is easier to promote it to the consumers. Hence, a similarity between the characteristic of the product and the celebrity's personality would bring an excellent advertisement result [7]. The celebrity brand ambassadors' traits such as their good attitude and physical attractiveness will bring huge impact on how consumers see the products [22].

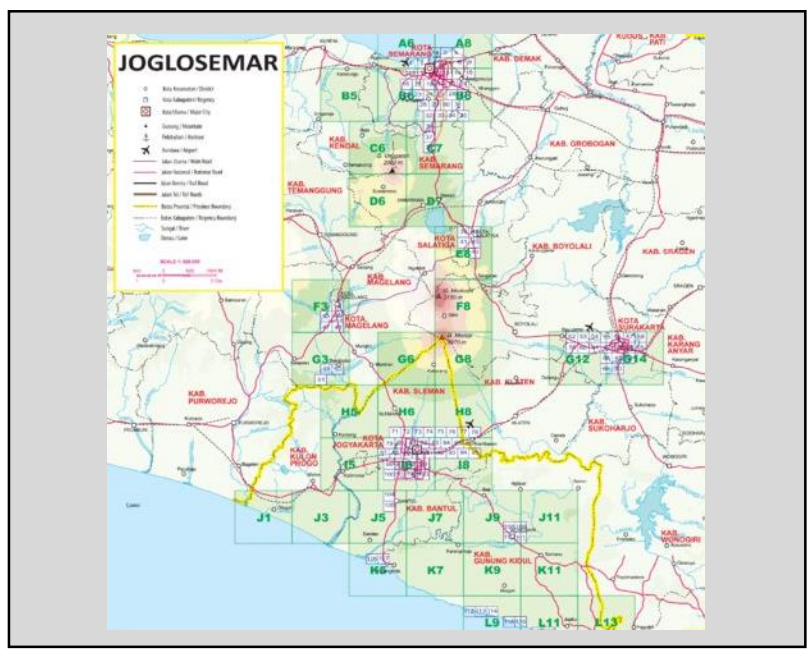

Figure 1. Map of research location (Yogyakarta, Solo, Semarang).

In recent years, the food and beverage industry in Indonesia has experienced an explosion of celebrity cake business. At least, there are 10 brands of celebrity cake in Yogyakarta, Solo, and Semarang such as Jogja Scrummy, Mamahke Jogja, Jogja Cushy Cheese, Bakpia Princess Cake, Solo Pluffy, Solovely, Solo Prabu, Semarang Wingkorolls, Semarang Roru Cake, and Kuenya Ayu, that indicate the high competition in this business. Some celebrities are trying to expand their profit out of their zone by creating culinary businesses

Corresponding author: safiraputami@gmail.com 
since their fame could really help to brand their product [43].

Equally important, researchers stated that considering the wide internet access that can connect the whole world, e-WOM also holds important role to help every economic agents. Information that the consumers (especially the young ones) get from e-WOM does not only help them to increase their satisfaction of purchasing something but also preventing any mistakes that may occur [6]. Social media as one of e-WOM platform, helps as a sharing platform to share their experiences toward certain products and/or services [49]. Therefore, this research aims to study the effects of celebrity brand ambassador and e-WOM (including quality and quantity of e-WOM as well as sender's expertise) on consumers' purchasing intention and the most influential variable on consumers' purchasing intention of celebrity cake in Indonesia (Yogyakarta, Solo, and Semarang).

\section{THEORETICAL BACKGROUND AND HYPOTHESES DEVELOPMENT}

\subsection{Theoretical Background}

\subsubsection{Celebrity Brand Ambassador}

According to Doucett, a brand ambassador is anyone who is passionate about the brand, is willing to talk about it, and may even volunteer brand information on her own [16]. Kitchen explained that a brand ambassador is a passionate individual for a particular services or products, but we believe that individual is a loyal and loud advocate that spreads the goodwill in the name of that companies, products, or services [36]. A brand ambassador's image in appearance, demeanour, values, and ethics are things that they must be able to represent through their traits [4]. One of a brand ambassador's duty is to make close connection with the target audiences as natural as possible [42].

A Brand ambassador is usually a well-trained, energetic teenager that was being recruited by a company to consistently promote their products as if it is applied to their daily life to gain the brand attention of the target audience. Being 'the face' of a product, a brand ambassador is expected to have very strong knowledge to the product so they will be able to explain it in every possible discussion [9]. It is important for the consumer to perceive the brand ambassador as someone that they can rely, trust and admire in order to create a good connection [30].

\subsubsection{Electronic Word of Mouth (e-WOM)}

Rachbini says that Electronic Word of Mouth (e-WOM) is a form of communication that rises with the extensive growth of the management of social media along with user generated content (UGC) [47]. E-WOM is an explanatory communication related to particular products or service through internet-based technology that happens between the economic agents (it could be producer and consumer, among fellow consumer, etc) [41]. E-WOM is an online exchanging information activity among the potential, actual, or former consumers about any products and services in which everyone can access or join [18].

In this research, e-WOM is viewed from three dimensions, including e-WOM quality, e-WOM quantity, and sender's expertise. The quality indicates the convincing strength of comments in an online message [2]. The quality of e-WOM can be observed using these following constructions: relevance, timeliness, accuracy, and comprehensiveness [12]. Moreover, helpful and convincing reviews or comments about the product could leave powerful impact on consumer see it and affects their purchasing intention $[5]$.

The total number of posted comments or reviews in social media is the key value to measure the quantity of e-WOM [12]. The difference between quantity in online reviews and advertising research is that quantity in online reviews focuses more to the amount of the comments or reviews rather than the number of the arguments which is used by advertising researches [26]. The advantage of online review is it helps the consumers to not make any mistakes and whether a product is really worth to purchase by checking at the amount of other consumer's shared reviews since it indicates how valuable and popular the product is [5].

Authoritativeness, expertness and competence are the values to see expertise of certain product [25]. Reviews as consumers' previous expertise over a product can influence perceived credibility of e-WOM communications [18]. As a respond, retailers have to be careful to handle those reviews since result showed sender's expertise is a big role from e-WOM [48].

\subsubsection{Purchase Intention}

Purchase intention is a plan to purchase products consumer think as most beneficial that fits their brand preference [21]. It is a considerate and willing behaviour in which one could say it is a combination between attitudes, responses, reaction, simple action, and desires someone to do something [34]. Intention is a plan to perform certain behaviour. Looking from the consumers' glasses, it refers to the plan of owning a product. It is supposed to provide connection between the internal process's reaction to the stimulus situation, and the actual acquisition or use of the product [10].

Purchase intention indicates how the consumers are willing to purchase certain products or services after considering and calculating that the product is valuable and worth to buy [3, 14, 20,35]. Intention to purchase something means to a scale which a consumers' plans to purchase online product in certain condition from the internet. The situation is usually related to the behaviour, perceptions, and attitudes of the consumers. According to the theory of reasoned action (TRA), intention to act determines volitional behaviour [31, 45]. Purchase 
intention is a consumer behavior in decision-making to consider the reason before they purchase something [40].

\subsection{Hypotheses Development}

\subsubsection{Effect of Celebrity Brand Ambassador on Purchase Intention}

The use of celebrity as brand ambassador aims at expanding the coverage of target market as well as increasing the popularity of the product through the celebrity's image known by the public. In other words, the image of the celebrity brand ambassador affects the image of the product. Therefore, a careful screening is required within the selection process of the celebrity brand ambassador since it has to suit the product's image that the corporation wants the public to acknowledge [47].

Celebrity brand ambassador significantly affects the purchase intention and the sales hike through both influential and causal factor. For instance, in the advertisement of beauty products, the advertised products will always be associated with the physical attractiveness of the celebrity. The consumers' perception will always be referred to the image that the celebrity portrays [7]. Thus, the following hypothesis is proposed:

H1: The celebrity brand ambassador positively affects consumers' purchase intention.

\subsubsection{Effect of e-WOM Quality on Purchase Intention}

Online feedback is one of the communication tools to introduce a product. The reviews or comments have to be understandable, helpful, and convincing as to attract and influence more prospective consumers. Utilizing clear dictions in a well-structured review over a product may lead to a high likelihood as well as willingness of purchasing the product. Moreover, the more credible and helpful the reviews are, the more likely the consumers are persuaded $[5,44]$.

The tendency of seeking approval and supporting validation from online reviews and comments can be used as one of the indirect advertisement tools. Through a certain review format, online sellers may have a place to accommodate positive and high-quality feedback. In conclusion, positive feedback increases the consumer purchase intention [13]. Thus, the hypothesis is proposed:

H2: The e-WOM quality positively affects consumers' purchase intention.

\subsubsection{Effect of e-WOM Quantity on Purchase Intention}

A large quantity of positive reviews indicates that the discussed product is well-known. And, this well-known quality increases the purchase intention. The large number of reviews and comments of the product shows that the product is believed and approved by a large number of people. This belief persuades the swing consumers to believe and approve that the product is worth-trying. As a result, the swing consumers will grow stronger confidence over the product [44]. The online review sources vary from a number of networking sites, including web boards, organizations official websites, online blogs, chat rooms, product review websites, and social networking sites [5].

These sources are the ones that the consumers depend on before purchasing certain products and services. In addition, the online platforms provide a transparent medium for the consumers to consider the product's popularity, the number of people that recommend the product, and the effect that they get after purchasing the product. The total number of reviews and star ratings represent the summary as well as conclude the overall quality of the product that will generate more purchase intention from the consumers. In short, the number of reviews in social networking sites has a certain extent of impact on the consumer purchase intention [15]. Thus, the following hypothesis is proposed:

H3: The e-WOM quantity positively affects consumers' purchase intention.

\subsubsection{Effect of Sender's Expertise on Purchase Intention}

Another factor that influence consumer purchase intention roots from sender's expertise. Recommendation and feedback written by sender who has expertise related to the product increases the consumers' believability towards the product. The label of expert assures the consumers to purchase the product since the expertise knowledge generates reliable and credible information over the product [13].

As a result, it influences the consumer perception and purchase intention. In brief, the more expert the sender is, the more perception of purchase intention may increase [33]. The willingness to buy a product is not only based on the close association or circumstance with the sender's information but also relied on the degree of expertise that the sender of the information has [29]. Thus, the following hypothesis is proposed:

H4: The sender's expertise positively affects consumers' purchase intention.

\section{RESEARCH MODEL AND METHODOLOGY}

\subsection{Research Model}

Throughout a thorough analysis of hypothesis development, the researcher proposed this model, as shown in figure (1). 


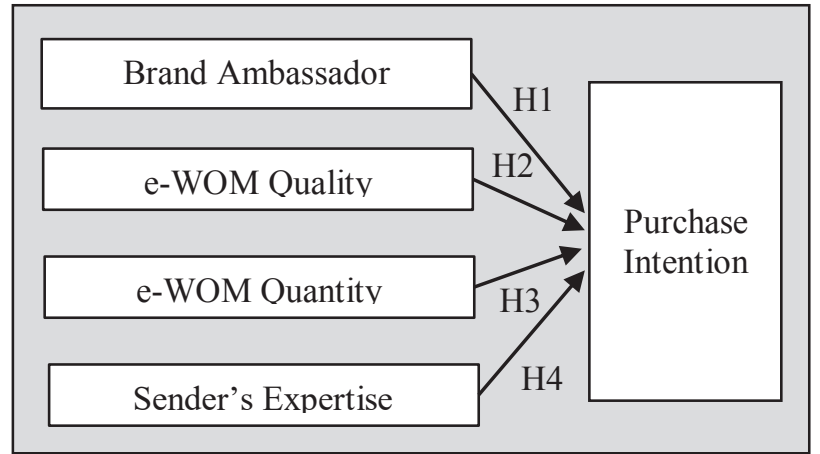

Figure 2. Proposed research model.

\subsection{Research Methodology}

\subsubsection{Research Population and Sample}

The research population is defined as all people who known the information of celebrity cake in Yogyakarta, Solo, and Semarang through online media. Convenience sampling technique has been used in data collection; the sample size was determined to be 100 respondents with the criteria are someone who known the information of celebrity cake in Yogyakarta, Solo, and Semarang through online media and never bought celebrity cake.

\subsubsection{Questionnaire and Data Collection}

The questionnaires for the research was created based on relevant literatures and used to collect data from the research sample. The questionnaire was distributed online through Google forms and consisted of three parts:

Part one is asking respondent's characteristics. The second part is collecting data for all research variables. Five-point Likert scale is used in this part, ranging from $(1=$ strongly disagree $)$ to $(5=$ strongly agree). Part three contains of open questions about independent variable. Open questions (essay) are used because it could explain the reason behind the respondent's answer.

\subsubsection{Instrument Test and Data Analysis Method}

After distributing the questionnaires, the data is analysed further through validity test, reliability test, classic assumption test, multiple linear regression, and hypotheses test. The main statistical analytical tool for the research is statistical analysis software.

The measurement of validity test is based on the comparison between the r-table and r-value. Each variable is regarded valid when the r-value is higher than the r-table. The r-table used in this current research is 0.361 while the r-value is seen from Corrected ItemTotal Correlation [38]. The measurement of reliability test is based on the value of Cronbach's Alpha. All indicators for each variable are categorized reliable when the Cronbach's Alpha is higher than 0.6 [24].
The classic assumption test consists of normality, multicollinearity, and heteroscedasticity. The distribution standard of the residual can be seen through the normality test, which is conducted through the Kolmogorov-Smirnov test [23]. The correlation between independent variables can be seen through the Multicollinearity test. It was seen from the value of Tolerance and VIF. It is passed when Tolerance is greater than 0.10 and VIF is less than 10 [23]. The variance error at different time frames of observation can be calculated with the Heteroscedasticity test that is conducted through Glejser test [23].

Multiple linear regressions will form a regression equation. Hypotheses test in this research consist of coefficient determination $\left(\mathrm{R}^{2}\right)$, F-test, and t-test. The analysis of this part mainly aims to identify the effect of independent variables (celebrity brand ambassador, eWOM quality, e-WOM quantity, and sender's expertise) to dependent variable (purchase intention).

\section{DATA ANALYSIS AND RESULTS}

\subsection{Sample Characteristics}

Table (1) exhibits the research sample characteristics. A filtered question was used to reveal if each respondent has a social media account to answer the questionnaire.

Table 1. Sample characteristics.

\begin{tabular}{|c|c|c|}
\hline Variable & Frequency & Percent \\
\hline $\begin{array}{l}\text { Gender } \\
\text { Males } \\
\text { Females }\end{array}$ & $\begin{array}{l}22 \\
78\end{array}$ & $\begin{array}{l}22 \\
78\end{array}$ \\
\hline $\begin{array}{l}\text { Cake brand (intent to } \\
\text { buy) } \\
\text { Jogja Scrummy } \\
\text { Mamahke Jogja } \\
\text { Jogja Cushy Cheese } \\
\text { Bakpia Princess Cake } \\
\text { Solo Pluffy } \\
\text { Solovely } \\
\text { Solo Prabu } \\
\text { Semarang Wingkorolls } \\
\text { Semarang Roru Cake } \\
\text { Kuenya Ayu }\end{array}$ & $\begin{array}{c}23 \\
30 \\
10 \\
5 \\
20 \\
1 \\
2 \\
1 \\
3 \\
5 \\
\end{array}$ & $\begin{array}{c}23 \\
30 \\
10 \\
5 \\
20 \\
1 \\
2 \\
1 \\
3 \\
5 \\
\end{array}$ \\
\hline $\begin{array}{l}\text { Origin } \\
\text { Yogyakarta } \\
\text { Solo } \\
\text { Semarang } \\
\text { Others }\end{array}$ & $\begin{array}{l}14 \\
12 \\
14 \\
60\end{array}$ & $\begin{array}{l}14 \\
12 \\
14 \\
60\end{array}$ \\
\hline $\begin{array}{l}\text { Age (y.o) } \\
<20 \\
20-30 \\
>30\end{array}$ & $\begin{array}{c}10 \\
89 \\
1\end{array}$ & $\begin{array}{c}10 \\
89 \\
1\end{array}$ \\
\hline $\begin{array}{l}\text { Last education } \\
\text { Primary School } \\
\text { Junior High School } \\
\text { Senior High School } \\
\text { Bachelor } \\
\text { Others }\end{array}$ & $\begin{array}{c}0 \\
2 \\
66 \\
25 \\
7\end{array}$ & $\begin{array}{c}0 \\
2 \\
66 \\
25 \\
7\end{array}$ \\
\hline
\end{tabular}




\begin{tabular}{|l|c|c|}
\hline Livelihood & 86 & 86 \\
Student & 3 & 3 \\
Government Employee & 6 & 6 \\
Private Employee & 3 & 3 \\
Entrepreneurship & 1 & 1 \\
Teacher/Lecturer & 1 & 1 \\
Others & & \\
\hline Income/month (Rp) & 79 & 79 \\
$\leq 1.800 .000,00$ & 11 & 11 \\
$1.800 .001,00-$ & & \\
$3.000 .000,00$ & 6 & 6 \\
$3.000 .001,00-$ & & \\
$4.800 .000,00$ & 3 & 3 \\
$4.800 .001,00-$ & & \\
$7.200 .000,00$ & 1 & 1 \\
$>7.200 .000,00$ & 100 & 100 \\
\hline Total & & \\
\hline
\end{tabular}

Source: Primary Data Analysis.

The result of table (1) shows that $78 \%$ respondents are women because women tend to be more easily influenced by online media in terms of shopping [17]. The majority respondents have intention to buy Mamahke Jogja cake. The majority respondents (60\%) came from outside the selected regions which means celebrity cake enthusiasts are very broad. For the age, $89 \%$ respondents were around $20-30$ years old who are active internet user according to APJII' survey. Lastly, the education of the respondents are $66 \%$ Senior High School students and the livelihood of the respondents are $86 \%$ students. The majority respondents based on their income explained as follow, 79\% samples have an income of $\leq \mathrm{Rp} 1.800 .000,00$ as most of them were still in college. Table (2) shows about the respondents' general activities on the online media.

Table 2. Sample activities.

\begin{tabular}{|l|c|c|}
\hline \multicolumn{1}{|c|}{ Variable } & Frequency & Percent \\
\hline \multicolumn{1}{|c|}{ Activity usually respondents do on online media } \\
\hline Chatting & 64 & 64 \\
Searching & 23 & 23 \\
products/services & 13 & 13 \\
Others & & \\
\hline \multicolumn{2}{|c|}{ Intensity of reading online reviews (in a day) } \\
\hline $1-3$ times & 73 & 73 \\
$4-6$ times & 16 & 16 \\
$7-9$ times & 2 & 2 \\
More than 10 times & 9 & 9 \\
\hline \multicolumn{2}{|c|}{ Online media to know about celebrity cake } \\
\hline Website & 4 & 4 \\
Instagram & 88 & 88 \\
Facebook & 1 & 1 \\
Line & 2 & 2 \\
Whatsapp & 0 & 0 \\
Youtube & 5 & 5 \\
\hline \multicolumn{1}{|c|}{ Know or don't know about celebrities } \\
\hline Know & 93 & 93 \\
Don't know & 7 & 7 \\
\hline Total & 100 & 100 \\
\hline
\end{tabular}

Source: Primary Data Analysis.
The result of the table (2) shows that chatting is the most common activity (64\%), followed by $23 \%$ browsing online products/services. It can be concluded that the respondents' main concern in using online media platform is not only to keep in touch with the others, but they may also look or get product information from their contact list [5]. Both activities are considered as e-WOM activity. The intensity of reading online reviews could be one until three times a day with average of $73 \%$. Table (2) shows that $88 \%$ respondents are finding out information about celebrity cake through Instagram; it is because celebrity brand ambassador usually promotes celebrity cake on Instagram. At last, 93\% respondents know about celebrities who become a brand ambassador because most of them have been famous for a long time.

\subsection{Instrument Test}

\subsubsection{Validity Test}

Validity test used to measure all indicators (celebrity brand ambassador [32], e-WOM quality [13], e-WOM quantity [13], sender's expertise [13], and purchase intention [1]). The result shows in Table (3). Based on Table (3), all indicators have higher r-value than the rtable, it means all indicator are valid and can be used in the questionnaire.

Table 3. Validity Test.

\begin{tabular}{|l|c|c|}
\hline \multicolumn{3}{|c|}{ Indicator Celebrity Brand Ambassador } \\
\begin{tabular}{|l|c|}
\hline \multicolumn{1}{|c|}{ r- } \\
table
\end{tabular} & $\begin{array}{c}\text { r- } \\
\text { value }\end{array}$ \\
\hline $\begin{array}{l}\text { Celebrities have the ability to } \\
\text { convey the intent of the message } \\
\text { during the promotion. }\end{array}$ & 0.361 & 0.681 \\
\hline Celebrities have good personality. & 0.361 & 0.567 \\
\hline $\begin{array}{l}\text { Celebrities have good interaction } \\
\text { when delivering message. }\end{array}$ & 0.361 & 0.658 \\
\hline Celebrities are familiar/famous. & 0.361 & 0.417 \\
\hline $\begin{array}{l}\text { Celebrities have the ability to } \\
\text { attract prospective buyers. }\end{array}$ & 0.361 & 0.786 \\
\hline $\begin{array}{l}\text { Celebrities say honestly according } \\
\text { to fhe fact when promoting } \\
\text { product. }\end{array}$ & 0.361 & 0.703 \\
\hline \multicolumn{3}{|c|}{ e-WOM Quality } \\
\hline The online review is clear. & 0.361 & 0.751 \\
\hline $\begin{array}{l}\text { The online review is } \\
\text { understandable. }\end{array}$ & 0.361 & 0.665 \\
\hline The online review is helpful. & 0.361 & 0.684 \\
\hline The online review is credible. & 0.361 & 0.756 \\
\hline $\begin{array}{l}\text { The online review has sufficient } \\
\text { reasons supporting the opinions. }\end{array}$ & 0.361 & 0.815 \\
\hline $\begin{array}{l}\text { In general, the quality of each } \\
\text { online review is high. }\end{array}$ & 0.361 & 0.781 \\
\hline $\begin{array}{l}\text { The number of online review is } \\
\text { large, inferring that the product is } \\
\text { popular. }\end{array}$ & 0.361 & 0.862 \\
\hline The quantity of online review & 0.361 & 0.818 \\
\hline
\end{tabular}




\begin{tabular}{|l|l|l|}
\hline $\begin{array}{l}\text { information is great, inferring that } \\
\text { the product has good sales. }\end{array}$ & \\
\hline $\begin{array}{l}\text { Highly ranking \& } \\
\text { recommendation, inferring that the } \\
\text { product has good reputations. }\end{array}$ & 0.361 & 0.724 \\
\hline \multicolumn{3}{|c|}{ Sender's Expertise } \\
\hline $\begin{array}{l}\text { The persons who provided online } \\
\text { review, I think they are } \\
\text { experienced. }\end{array}$ & 0.361 & 0.633 \\
\hline $\begin{array}{l}\text { The persons who provided online } \\
\text { review, I think they have abundant } \\
\text { knowledge toward the product. }\end{array}$ & 0.361 & 0.842 \\
\hline $\begin{array}{l}\text { The persons who provided online } \\
\text { review, I think they have the } \\
\text { ability on judgment. }\end{array}$ & 0.361 & 0.776 \\
\hline $\begin{array}{l}\text { This person provided some } \\
\text { different ideas than other sources. }\end{array}$ & 0.361 & 0.747 \\
\hline $\begin{array}{l}\text { This person mentioned some } \\
\text { things I had not considered. }\end{array}$ & 0.361 & 0.744 \\
\hline \multicolumn{3}{|c|}{ Purchase Intention } \\
\hline $\begin{array}{l}\text { I am interested to buy celebrity } \\
\text { cake. }\end{array}$ & 0.361 & 0.898 \\
\hline $\begin{array}{l}\text { I think of celebrity cake as a } \\
\text { choice while buying cake } \\
\text { products. }\end{array}$ & 0.361 & 0.922 \\
\hline $\begin{array}{l}\text { I will give efforts to buy celebrity } \\
\text { cake. }\end{array}$ & 0.361 & 0.885 \\
\hline $\begin{array}{l}\text { I have the intention to buy } \\
\text { celebrity cake in the future. }\end{array}$ & 0.361 & 0.879 \\
\hline Soure Primy Da Anlys
\end{tabular}

Source: Primary Data Analysis.

\subsubsection{Reliability Test}

Table (4) shows the reliability coefficients for all variables which ranged at intervals 0.711 to 0.916 . The Cronbach's Alpha of all indicators for each variable are higher than 0.6 , meaning that all variables are reliable.

Table 4. Reliability Test.

\begin{tabular}{|l|c|c|}
\hline \multicolumn{1}{|c|}{ Variables } & $\begin{array}{c}\text { Number } \\
\text { of Items }\end{array}$ & $\begin{array}{c}\text { Cronbach's } \\
\text { Alpha }\end{array}$ \\
\hline Brand Ambassador & 6 & 0,711 \\
\hline e-WOM Quality & 6 & 0,835 \\
\hline e-WOM Quantity & 3 & 0,724 \\
\hline Sender's Expertise & 5 & 0,792 \\
\hline Purchase Intention & 4 & 0,916 \\
\hline
\end{tabular}

Source: Primary Data Analysis.

\subsection{Regression}

\subsubsection{Classic Assumption Testing}

As stated in Table (5), the residuals of four relationships follow the normal distribution based on KolmogorovSmirnov test. The sig. value is $0.561>$ alpha value 0.05 that indicates the test distribution is normal.
Table 5. Normality Test.

\begin{tabular}{|l|c|}
\hline & Standardized Residual \\
\hline $\mathrm{N}$ & 100 \\
\hline Test Statistic & 0.790 \\
\hline Asymp. Sig. (2-tailed) & 0.561 \\
\hline
\end{tabular}

Source: Primary Data Analysis.

For the multicollinearity test as stated in Table (6), it can be summed up that multicollinearity does not exist between the independent variables because all values of Tolerance is greater than 0.10 and VIF is less than 10 .

Table 6. Multicollinearity Test.

\begin{tabular}{|l|c|c|}
\hline \multirow{2}{*}{\multicolumn{1}{|c|}{ Variables }} & \multicolumn{2}{c|}{$\begin{array}{c}\text { Collinearity } \\
\text { Statistics }\end{array}$} \\
\cline { 2 - 3 } & Tolerance & VIF \\
\hline $\begin{array}{l}\text { Celebrity Brand } \\
\text { Ambassador }\end{array}$ & 0,544 & 1,837 \\
\hline e-WOM Quality & 0,627 & 1,596 \\
\hline e-WOM Quantity & 0,673 & 1,485 \\
\hline Sender's Expertise & 0,890 & 1,124 \\
\hline
\end{tabular}

Source: Primary Data Analysis.

Table (7) shows that they are homoscedasticity instead of heteroscedasticity, because the sig. of Glejser Test $>$ alpha value 0.05 .

Table 7. Heteroscedasticity Test.

\begin{tabular}{|l|c|}
\hline \multicolumn{1}{|c|}{ Variables } & Sig. of Glejser Test \\
\hline $\begin{array}{l}\text { Celebrity Brand } \\
\text { Ambassador }\end{array}$ & 0.270 \\
\hline e-WOM Quality & 0.647 \\
\hline e-WOM Quantity & 0.671 \\
\hline Sender's Expertise & 0.951 \\
\hline
\end{tabular}

Source: Primary Data Analysis.

\subsubsection{The Equation of Multiple Linear Regression}

The equation model is formed from the constant value and regression coefficient values which can be seen from the value of B in the Unstandardized Coefficients' table. Based on the regression test, the regression equation is formed as follows:

$$
Y=\alpha+b_{1} X_{1}+b_{2} X_{2}+b_{3} X_{3}+b_{4} X_{4}+e
$$

$$
Y=-5.962+0.360 X_{1}+0.296 X_{2}+0.056 X_{3}+0.213 X_{4}+
$$

Where $\mathrm{Y}$ is the Purchase Intention; $\mathrm{X}_{1}$ is the Celebrity Brand Ambassador; $\mathrm{X}_{2}$ is the e-WOM Quality; $\mathrm{X}_{3}$ is the e-WOM Quantity; $\mathrm{X}_{4}$ is the Sender's Expertise; and $e$ is the error.

\subsubsection{Hypothesis Testing}

With the purpose of testing the research hypotheses, the researcher depended on multiple regression analysis to examine the influence of independent variables 
perceived celebrity brand ambassador, e-WOM quality, e-WOM quantity, and sender's expertise on the dependent variable purchase intention and the most influential variable on purchase intention.

Based on Table (8), the variance proportion for $33.7 \%$ of consumer purchase intention can be explained by all independent variables (celebrity brand ambassador, e-WOM quality, e-WOM quantity, and sender's expertise) according to Adjusted $\mathrm{R}^{2}$ value. While the remaining $66.3 \%$ is influenced by the other variables which is not examined in this research model such as taste, packaging, price, location, socio-economic and environmental, etc.

Table 8. Model Summary.

\begin{tabular}{|c|c|c|c|c|}
\hline Model & $\mathbf{R}$ & $\mathbf{R}^{\mathbf{2}}$ & $\begin{array}{c}\text { Adjusted } \\
\mathbf{R}^{\mathbf{2}}\end{array}$ & $\begin{array}{c}\text { Std. Error } \\
\text { of the } \\
\text { Estimates }\end{array}$ \\
\hline 1 & 0.603 & 0.363 & 0.337 & 2.709 \\
\hline
\end{tabular}

Source: Primary Data Analysis.

Table (9) shows that the model of this research is significant because of the sig. value in ANOVA table is 0.000. This value is smaller than Alpha value 0.05. It means the independent variables (celebrity brand ambassador, e-WOM quality, e-WOM quantity, and sender's expertise) simultaneously have a significant influence on consumers' purchase intention of celebrity cake.

Table 9. ANOVA.

\begin{tabular}{|l|c|c|c|c|c|}
\hline Model & $\begin{array}{c}\text { Sum of } \\
\text { Squares }\end{array}$ & df & $\begin{array}{c}\text { Mean } \\
\text { Square }\end{array}$ & F & Sig. \\
\hline Reg. & 397,860 & 4 & 99,465 & 13,554 & 0,000 \\
\hline Residual & 697,140 & 95 & 7,338 & & \\
\hline Total & 1095,000 & 99 & & & \\
\hline
\end{tabular}

Source: Primary Data Analysis.

Table (10) shows the relationship of independent variables (celebrity brand ambassador, e-WOM quality, e-WOM quantity, and sender's expertise) towards dependent variable (purchase intention) partially.

Table 10. Coefficients.

\begin{tabular}{|l|c|c|c|c|}
\hline \multirow{2}{*}{ Model } & \multicolumn{2}{|c|}{$\begin{array}{c}\text { Unstandardized } \\
\text { Coefficients }\end{array}$} & \multirow{2}{*}{ T } & \multirow{2}{*}{ Sig. } \\
\cline { 2 - 3 } & B & $\begin{array}{c}\text { Std. } \\
\text { Error }\end{array}$ & & \\
\hline (Constant) & $-5,962$ & 2,609 & $-2,285$ & 0,025 \\
\hline Celebrity BA & 0.360 & 0,128 & 2,812 & 0,006 \\
\hline e-WOM ql & 0,296 & 0,118 & 2,513 & 0,014 \\
\hline e-WOM qn & 0,056 & 0,144 & 0,389 & 0,698 \\
\hline S Expertise & 0,213 & 0,110 & 1,932 & 0,056 \\
\hline
\end{tabular}

Source: Primary Data Analysis.

H1: The celebrity brand ambassador positively affects consumers' purchase intention.

As shown in Table (10), the sig. value of celebrity brand ambassador is $0.006<$ alpha value 0.05 . Hence, the findings point out that there is a positive effect of celebrity brand ambassador on consumers' purchase intention. Thus, the findings offer support to accept $\mathrm{H} 1$.

H2: The e-WOM quality positively affects consumers' purchase intention.

As shown in Table (10), the sig. value of e-WOM quality is $0.014<$ alpha value 0.05 . Hence, the findings point out that there is a positive effect of e-WOM quality on consumers' purchase intention. Thus, the findings offer support to accept $\mathrm{H} 2$.

H3: The e-WOM quantity positively affects consumers' purchase intention.

As shown in Table (10), the sig. value of e-WOM quantity is $0.698>$ alpha value 0.05 . Hence, the findings point out that there is no significant effect of e-WOM quantity on consumers' purchase intention. Thus, the findings offer support to reject $\mathrm{H} 3$.

H4: The sender's expertise positively affects consumers' purchase intention.

As shown in Table (10), the sig. value of sender's expertise is $0.056>$ alpha value 0.05 . Hence, the findings point out that there is no significant effect of sender's expertise on consumers' purchase intention. Thus, the findings offer support to reject $\mathrm{H} 4$.

\section{DISCUSSIONS AND CONCLUSIONS}

Prior research has studied the impact of celebrity brand ambassador and electronic word of mouth (e-WOM) in various researches, marketers need to be more aware and analyse how celebrity brand ambassador and e-WOM as a marketing strategy might influence consumers' purchase intention. The findings of the data analysis point out that there is a positive effect of celebrity brand ambassador on purchase intention. A famous celebrity that is well-known to have good personalities and is excellent at interacting with people/consumers will increase consumers' purchase intention. The result is equivalent with previous literatures that celebrity brand ambassador positively affects consumers' purchase intention [7, 32].

The second result shows that there is a positive effect of e-WOM quality on purchase intention. While looking for the information about celebrity cake, respondents immediately focus on the content of online reviews. Comments that are clear, logical and persuasive, with sufficient reasons for the specific aspect about the product, have a strong positive effect on the purchase intention. The result is equivalent with previous literatures that the e-WOM quality positively affects consumers' purchase intention $[11,15]$.

Furthermore, the result shows that there is no effect of e-WOM quantity and sender's expertise on purchase intention. When reading online reviews, respondents were more interested with the content of online reviews rather than seeing the number of reviews and the sender's expertise. This result is equivalent with previous literatures e-WOM quantity [39]; sender's expertise [37]. The last result shows that the most influential variable on consumers' purchase intention of celebrity cake is a celebrity brand ambassador with the regression coefficient value 0.360 . 


\section{RECOMMENDATIONS AND FUTURE RESEARCH}

In order to enhance the celebrity brand ambassador and e-WOM quality on consumers' purchase intention of celebrity cake in Indonesia, there are two recommendations proposed by the writer. The first recommendation is the management of celebrity cake hold a mini talk show; invite one or more celebrity brand ambassador as guest star. The event organizer can provide free samples of celebrity cake, discount coupons and merchandises. The mini talk show should be free and conducted on the weekend in the venue that is easy to reach like public space in the middle of the city. The second recommendation is the employee of celebrity cake requested reviews from consumers who were buying their products in the outlet and had previously tried the product, and then the reviews should be uploaded to social media. Celebrity brand ambassador can also comment about celebrity cake.

Finally, future research in this field may take another sample of celebrity cake or online product, or to extend the research model and related topics based on latest literatures, in order to enrich this growing area of research.

\section{ACKNOWLEDGEMENT}

The author is grateful to all parties (family, friends, and all lecturers and staffs of Agribusiness Department, Faculty of Agriculture, Universitas Sebelas Maret, Surakarta) for the full psychologically and financially support granted to this research project.

\section{REFERENCES}

1. A.A. Widjaja, iBuss Mgmt, 3, 4 (2015)

2. A. Bhattacherjee, S. Clive, MSI Qtly, 30, 4 (2006)

3. A. Madahi, I. Sukati, Int. Bus. Res, 5, 8 (2012)

4. A. Port, Annabel vs the internet: the time I infiltrated google $H Q$ and other adventures (Unbound, London, 2018)

5. A.Q. Bataineh, Int. J. Mktg. Stud, 7, 1 (2015)

6. A. Thoumrungrejo, The influence of social media intensity and ewom on conspicuous consumption, 148, 7 - 15 (2014)

7. Aurangzeb, G. Sami, Z. Asrar, S.A. Bhutto, J. Mktg. and Consr. Res, 31, 14 - 21 (2017)

8. B. Lonsway, Making leisure work: architecture and the experience economy (Routledge, New York, 2009)

9. B. Mullen, C. Johnson, The psychology of consumer behavior (Lawrence Erlbaum Associates, New Jersey, 1990)

10. B. Widagdo, M.E. Saputri, MBA, Pengaruh electronic word of mouth terhadap purchase intention melalui media social twitter pada chatime Indonesia, 4, 2904 - 2908 (2017)

11. C.M.K. Cheung, D.R. Thadani, The effectiveness of electronic word-of-mouth communication: a literature analysis, 329 - 345 (2010)

12. C. Lin, Y.S. Wu, J.C.V. Chen, Electronic word-ofmouth: the moderating roles of product involvement and brand image, 29 - 31 (2013)

13. D.B. Whitlark, M.D. Geurts, M.J. Swenson, J. of Bus. Fcst. Meth. \& Sys, 12, 3 (1993)

14. D.H. Park, J. Lee, I. Han, Int. J. of Elec. Com, 11, 4 (2007)

15. E. Doucett, Creating your library brand, communicating your relevance and value to your patrons (American Library Association, Chicago, 2008)

16. E.E. Lubis, J. Paralella, 1, 2 (2014)

17. E. Ismagilova, Y.K. Dwivedi, E. Slade, M.D. Williams, Electronic word of mouth (ewom) in the marketing context (a state of the art analysis and future directions) (Springer, Wales, 2017)

18. F. Xiaorong, Z. Bin, X. Qionghonh, X. Liuli, C. Yu, As. J. of Bus. Res, 1, 2 (2011)

19. G. Bowen, W. Ozuem, Leveraging computermediated marketing environments (IGI Global, Hershey, 2019)

20. G.P. Lantos, Consumer behavior in action: real-life applications for marketing managers (Routledge, New York, 2015)

21. G. Radha, P. Jija, Int. J. of Sci. and Res. Pub, 3, 11 (2013)

22. I. Ghozali, Ekonometrika teori, konsep, dan aplikasi dengan IBM SPSS 22 (Badan Penerbit Universitas Diponegoro, Semarang, 2014)

23. J. Arifin, SPSS 24 untuk penelitian dan skripsi (PT. Elex Media Komputindo, Jakarta, 2017)

24. J.H. Huang, Y.F. Chen, Psy. \& Mktg, 23, 5 (2006)

25. J. Lee, D.H. Park, I. Han, Elec. Com. Res. And Apps, 7, 3 (2008)

26. J.R. Rossiter, A. Smidts, J. of Bus. Res, 65, 6 (2012)

27. K. Nirushan, Ind. J. of Res. Mgmt. Bus. Soc. Sci, 4, 2 (2017)

28. L.E. Swayne, M. Dodds, Encyclopedia of sports management and marketing (SAGE Publications, Inc, California, 2011)

29. L.L. Brennan, V.E. Johnson, Computer-mediated relationships and trust: managerial and organizational effects (IGI Global, Hershey, 2008)

30. M.A. Kusuma, I.W. Santika, E-J. Mgmt. Unud, 6, 4 (2017)

31. M. Gurcu, S. Korkmaz, Int. J. of Health Mgmt. and Tour, 3, 1 (2018)

32. N.M. Suki, Handbook of research on leveraging consumer psychology for effective customer engangement (IGI Global, Hershey, 2017) 
33. N.Z. Hosein, J. of Mgmt. \& Mktg. Res, 9 (2012)

34. P.J. Kitchen, Marketing metaphors and metamorphosis (Palgrave Macmillan, New York, 2008)

35. S.E.P. Widoyoko, Teknik Penyusunan Instrumen Penelitian (Pustaka Pelajar, Yogyakarta, 2012)

36. S.K. Zangeneh, R. Mohammadkazemi, M. Rezvani, Mgmt. Sci. Letter, 4, 2433 - 2440 (2014)

37. S.S.H. Shah, J. Aziz, A.R. Jaffari, S. Waris, W. Ejaz, As. J. of Bus. Mgmt, 4, 2 (2012)

38. S.W. Litvin, R.E. Goldsmith, B. Pan, Tour. Mgmt, 29, $458-468$ (2008)

39. T.C. Melewar, S. Gupta, Strategic international marketing (Palgrave Macmillan, New York, 2012)

40. T. Susanto, M.S.D. Harahap, Analisis penggunaan celebrity brand ambassador (studi kasus celebrity brand ambassador Nagita Slavina, Raffi Ahmad dalam Gigieatcake, 82 - 87 (2017)

41. T.T. Huyen, J. Costello, J. of Promo. Comm, 5, 2 (2017)

42. V. Mirabi, H. Akbariyeh, H. Tahmasebifard, J. of Multidiscip. Engr. Sci. and Tech, 2, 1 (2015)

43. W. Hong, J.Y.L. Thong, K.Y. Tam, J. of Mgmt. Info. Sys, 21, 3 (2004)

44. W. Rachbini, IOSR J. of Buss. and Mgmt, 20, 8 (2018)

45. W.F.W. Zulkiffli, L.M. Hong, S.I.F. Ramlee, M.N.M. Yunoh, R.C. Aziz, Int. J. of Acct. Fin. and Bus, 2, 6 (2017)

46. X. Wang, H.H. Teo, K.K. Wei, J. of Elec. Com. Res, 16, $3(2015)$ 